\title{
Effect of Organic Manures and Bio-Inoculants on Growth, Yield and Quality of Rice (Oryza sativa L.)
}

\author{
Ram Narayan Meena, Ashvin Kumar Meena*, Kamlesh Meena, \\ Swathy Ullas and Sanjay Kumar
}

Department of Agronomy, Institute of Agricultural Sciences, Banaras Hindu University, Varanasi-221005, India

*Corresponding author

\section{Keywords}

Organic manure,

Bio-inoculants,

Rice, Quality, Yield

Article Info

Accepted:

15 October 2019

Available Online:

10 November 2019

\section{A B S T R A C T}

A field experiment was conducted to evaluate the response of manurial treatment and bio inoculants on growth, yield and quality of rice at Agricultural Research Farm of Banaras Hindu University during kharif season of 2015. The experiment comprised four manurial treatment in main plot and four bio inoculants in sub plot. Experiment was laid out in split plot design and replicated thrice. The results indicated that significantly higher growth attribute, yield attribute and quality parameter of rice were recorded with the application of $50 \%$ of RDN as FYM $+50 \%$ as vermicompost (MT-3). Among the bio inoculants treatments, PSB + Azotobacter/Rhizobium resulted in significantly higher growth, yield and quality parameters and remains at par with application of PSB.

\section{Introduction}

Rice (Oryza sativa L.) provides more than half the daily food for one of every three persons in the world, especially for south-eastern Asia, where $90 \%$ of the world production of rice are grown and consumed. At global level, it occupies an area of about 163.51 million ha with production and productivity of 498.65 million tonnes and 4.55 tonnes/ha, respectively (USDA, 2018). India ranks first in respect of area 44.50 million ha second in production 115.63 million tonnes with average productivity 3.90 tonnes/ha (USDA, 2018). The burgeoning population pressure has forced many countries to use chemicals and fertilizers to increase the farm productivity for meeting their ever increasing food requirements. The prolonged and over usage of chemicals has, however, resulted in human and soil health hazards along with environmental pollution. Supplementation of entire $\mathrm{N}$ through FYM sustains crop productivity at much lower level. Since, the 
estimates of NPK availability from organic sources are based on total nutrient content, efficiency of these sources to meet the nutrient requirement of crops is not as assured as mineral fertilizers but the conjoint use of chemical fertilizers along with various organic sources is capable of sustaining higher crop productivity, improving soil quality and productivity on long term basis (Yadav et al., 2013). The soil flora and fauna play an important role in soil development. Microbiological activity in the root zone is important to soil acidity and for nutrient cycling. Microbial inoculants, so-called biofertilizers, are a promising technology to reduce the use of conventional inorganic fertilizers. Many of them can serve as biofertilizers as they are able to fix nitrogen $(\mathrm{N})$, help to access nutrients such as phosphorus (P) and $\mathrm{N}$ from organic fertilizers and soil stocks, improve drought tolerance, improve plant health or increase salt tolerance (Vessey, 2003).

\section{Materials and Methods}

The field experiment was conducted during kharif season 2015 at Agricultural Research Farm, Institute of Agricultural Sciences, Banaras Hindu University, Varanasi, India located at $25^{\circ} 18^{\prime} \mathrm{N}$ latitude, $83^{\circ} 03^{\prime} \mathrm{E}$ longitude and at altitude of 75.7 MSL of IndoGangetic region of eastern U.P. (India). The soil of experimental site was sandy clay loam, 7.32 soil $\mathrm{pH}$ ( $\mathrm{pH}$ meter), $0.40 \%$ organic carbon (Walkley and Black, 1934), 180.50 $\mathrm{kg} / \mathrm{ha}$ available nitrogen (Subbiah and Asija, 1956), $18.34 \mathrm{~kg} / \mathrm{ha}$ available phosphorus (Olsen et al., 1954) and $208.42 \mathrm{~kg} / \mathrm{ha}$ available potassium (Jackson, 1973). The experiment was laid out in split plot design consisting 16 treatment combinations and were replicated thrice. The experiment comprised four manurial treatment viz. $100 \%$ of RDN as FYM $\left(\mathrm{T}_{1}\right), 100 \%$ of RDN as Vermicompost $\left(\mathrm{T}_{2}\right)$ $50 \%$ of RDN as FYM $+50 \%$ as
Vermicompost $\left(\mathrm{T}_{3}\right) 100 \%$ of $\mathrm{RDN}$ through inorganic sources $\left(\mathrm{T}_{4}\right)$ assigning to main plot. Four bio inoculants viz. Control $\left(\mathrm{T}_{1}\right)$, Azotobacter/Rhizobium ( $\left.\mathrm{T}_{2}\right)$, PSB $\left(\mathrm{T}_{3}\right), \mathrm{PSB}+$ Azotobacter/Rhizobium $\left(\mathrm{T}_{4}\right)$ were allocated to subplot. Recommended doses of nitrogen, phosphorus and potassium $\left(\mathrm{N}, \mathrm{P}_{2} \mathrm{O}_{5}\right.$ and $\left.\mathrm{K}_{2} \mathrm{O}\right)$ were supplied through urea $(46 \% \mathrm{~N})$, DAP $\left(46 \% \mathrm{P}_{2} \mathrm{O}_{5}\right.$ and $\left.18 \% \mathrm{~N}\right)$ and muriate of potash $\left(60 \% \quad \mathrm{~K}_{2} \mathrm{O}\right)$ respectively. Uniform basal application of phosphorus and potassium was made to all the plots. Half dose of nitrogen was applied as basal and remaining half dose applied in two equal splits at tillering and panicle initiation stages as per treatment requirement. Quantity of FYM and vermicompost to be applied were calculated as per their treatment requirement and thoroughly spread and mixed into respective plots. Bio inoculants were mixed with FYM and vemicompost as per treatment requirement before transplanting. Seedlings of 25 days old were transplanted at $20 \times 15 \mathrm{~cm}$ spacing under puddle conditions. The other crop management practices were followed as per standard recommendations. Five hills in the net plot area were randomly selected and tagged for recording the observation.

\section{Results and Discussion}

\section{Growth attributes}

The data presented in Table 1 indicated that plant height increased with advancement in crop age up to 90 DAT (days after transplanting). The highest plant height was recorded with treatment MT-3 (50\% of RDN as FYM $+50 \%$ as vermicompost), followed by MT-2 (100\% of RDN as vermicompost); whereas the minimum plant height at 90 DAS $(92.3 \mathrm{~cm})$ was observed in MT-4 (100\% of RDN through inorganic sources). Among the bio inoculant treatments, BI-4 recorded significantly taller plants at harvest $(104.6 \mathrm{~cm})$ which were at par to that recorded with 
application of BI-3. Manurial treatments had significant effect number of tillers per $\mathrm{m}^{2}$ at all the stages of crop growth. The MT-3 produced significantly higher number of tillers than other treatments. Among different bio inoculants treatments, BI-4 recorded significantly highest number of tillers per $\mathrm{m}^{2}$ which was statistically similar to application of BI-3 followed by BI-2.

The highest dry matter was recorded with treatment MT-3 (50\% of RDN as FYM + 50\% as vermicompost), followed by MT-2 (100\% of RDN as vermicompost); whereas the minimum drymatter was observed in MT-4 (100\% of RDN through inorganic sources). Among the bio inoculant treatments, BI-4 recorded significantly higher dry matter at harvest) which were at par to that recorded with application of BI-3. Govindan and Bagyaraj (1995) also conduct the field experiment of rice with biofertilizers inoculation and reported that biofertilizers inoculation enhanced shoots and root growth. Similar results are found by Rodriguez and Fraga (1996). This is in agreement with the findings of Devasenamma et al., (1999) and Nayak et al., (1986). Prasad and Singh (1984) also reported the combined effect of inoculation of biofertilizers in rice with application of $\mathrm{N}$ increased number of tillers, growth, nutrient uptake and yield of rice.

\section{Yield attributes and quality parameter}

The highest yield (4347 $\mathrm{kg} \mathrm{ha}^{-1}$ ), yield attributes and quality parameters were recorded with treatment MT-3 $(50 \%$ of RDN as $\mathrm{FYM}+50 \%$ as vermicompost), followed by MT-2 (100\% of RDN as vermicompost); whereas the minimum yield, yield attributes and quality parameters were observed in MT4
(100\% of RDN through inorganic sources). Among the bio inoculant treatments, BI-4 recorded significantly higher yield, yield attributes and quality parameters which were at par to that recorded with application of BI3. Meena et al., (2019) reported that increase $\mathrm{N}$ level brought about significant increase in grain yield. The grain yield of rice was also increased by inoculation of biofertilizers (Jayaraman, 1990). The increase in yield due to biofertilizers inoculates may not be solely due to $\mathrm{N}$ fixation or phosphate solubilization, but because of several other factors such as release of growth promoting substances, control of plant pathogen, proliferation of beneficial organism in the Azotobactor and PSB. These findings are in accordance with Kundu and Gaur (1982). Solubilizations of inorganic phosphate in the soil (PSB) make them available to the crop and resulted in better yield. It also produced a phytohormone (IAA) which increased its nutrient absorption capacity from the soil. These findings were in accordance with Datta et al., (1994) and Mudenoor (2002). The response to mixed culture inoculation was more than that for single culture, showing the synergistic effect of two types of organism. The significant response was mainly due to the supply of two major nutrients $\mathrm{N}$ and $\mathrm{P}$. Significant positive yield response in transplanted rice observed a statistically with biofertilizers (Rao et al., 1983) and N fertilizers (Meena et al., 2018).

From present study it can be concluded that application of $50 \%$ of RDN as FYM + 50\% as vermicompost is good option for significantly higher growth attribute, yield attribute and quality parameter of rice. Among the bio inoculants PSB + Azotobacter/Rhizobium resulted in significantly higher growth, yield and quality parameters of rice. 


\begin{tabular}{|c|c|c|c|c|c|c|c|c|}
\hline \multicolumn{9}{|c|}{ Manurial Treatment (MT) } \\
\hline MT-1 & 96.6 & 262 & 828 & 236 & 26.2 & 3917 & 4766 & 78.3 \\
\hline MT-2 & 103.8 & 276 & 872 & 246 & 27.9 & 4059 & 5022 & 77.7 \\
\hline MT-4 & 92.3 & 235 & 749 & 198 & 26.7 & 3288 & 4107 & 79 \\
\hline SEm \pm & 1.7 & 7.1 & 24 & 6 & 0.4 & 108 & 138 & 0.7 \\
\hline CD at $5 \%$ & 6 & 26 & 84 & 23 & NS & 383 & 484 & NS \\
\hline \multicolumn{9}{|c|}{ Bio Inoculant (BI) } \\
\hline BI-1 & 99.3 & 238 & 755 & 207 & 25.9 & 3474 & 4302 & 76.6 \\
\hline BI-2 & 101.9 & 302 & 954 & 263 & 27.6 & 4375 & 5439 & 79.3 \\
\hline CD at $5 \%$ & 3.4 & 18 & 53 & 16 & 0.9 & 237 & 301 & 1.6 \\
\hline
\end{tabular}




\section{References}

Datta, D. S. K., Neue, H. U., Senadhira, D., Quijano, C. 1994. Success in rice improvement for poor soils. In: Proceedings of the Work- shop on Adaptation of Plants to Soil Stresses, 1-4 August 1993, University of Nebraska, Lincoln, Nebraska. INTSORMIL Publication No. 94-2. Lincoln, Nebraska (USA): University of Nebraska. p 248268.

Devasenamma, V., Reddy, M. R. and Rajan, M. S. S. 1999. Effect of varying levels of nitrogen on growth and nitrogen uptake of rice hybrids. Andhra Agric. J. 46: 124125.

Govindan, N. and Bagyaraj, D. J. 1995. Field response of wetland rice to Azospirillum noculation. J. Soil Biol. \& Ecol., 1 5(1): 17-22.

Jackson M L. 1973. Soil chemical analysis. Prentice Hall of India Pvt. Ltd, New Delhi.

Jayaraman, P. and Kalyanasundaram, I. 1990. Natural Occurrence of toxigenic fungi and mycotoxinmnce bran. Mycopathologla. 110:81-85.

Kundu, B. S. and Gaur, A. C. 1982. Yield increase of wheat after inoculation with $A$. chroococcum and phosphobacteria. Curr. Sci. 51,291-293.

Meena, A. K., Singh, D. K., Pandey, P. C., and Nanda, G. 2019. Dynamics of dry matter and nitrogen distribution in transplanted rice on mollisols, Journal of Plant Nutrition. 42(7): 749-758.

Meena, A. K., Singh, D. K., Pandey, P. C., Nanda, G. 2018. Growth, yield, economics, and nitrogen use efficiency of transplanted rice (Oryza sativa L.) as influenced by different nitrogen management practices through neem (Azadirachta indica) coated urea. International Journal of Chemical Studies. 6(3): 1388-1395.
Mudenoor, M. G., 2002. Effect of micronutrient supplemented Azospirillum biofertilizers on maize (Zea mays L.). M.Sc. (Agri.) thesis, University of Agricultural Sciences, Dharwad.

Nayak, D. N., Ladha, J. K. and Watanabe, I. 1986. The fate of marker Azospirillum lipofentm inoculated into rice and its effect on growth, yield and $\mathrm{N}_{2}$ feeding by ${ }^{15} \mathrm{~N}$ dilution techniques. Biol. Fertil. Soils. 2: 7-14.

Prasad, J. and Singh, R. S. 1984. Effect of Azolla, seedling bacterization with Azotobactera and Azospisillum with and without nitrogen in paddy (Oryza sativa). Indian J. Agric. Res., 18: 240-245.

Rao, B., Barros, A. J. G. C. and Adusumilli, M.S. 1983. Lateritic gold project. In: A.J. Melfi and A. Car- valho (Editors), Lateritisation Processes. Proc. 2nd Int. Semin. of Lateritisation Processes, S o Paulo, pp. 159-176.

Rodríguez, H., Goire, I., Rodríguez, M. 1996. Caracterización de cepas de Pseudomonas solubilizadoras de fósforo. Rev ICIDCA. 30:47-54.

Subbiah B V, Asija G L. 1973. A rapid procedure for estimation of available nitrogen in soils, Current Sci, 28(8): 259-260.

USDA 2019. World Agricultural Production. Circular Series WAP, 7-19.

Vessey, K. J. 2003. Plant growth promoting rhizobacteria as biofertilizers. Plant Soil. 25: 557-586.

Walkley A, Black C A. 1934. Estimation of soil organic carbon by the chromic acid titration method. Soil Science, 37: 29-38.

Yadav, R. L., Dwivedi, B. S., Prasad, K., Tomar, O. K., Shurpali, N. J., Pandey, P. S. 2013. Yield trends and changes in soil organic $\mathrm{C}$ and available NPK in a long-term ricewheat system under integrated use of manures and fertilizers. Field Crops Research. 68: 219-246.

\section{How to cite this article:}

Ram Narayan Meena, Ashvin Kumar Meena, Kamlesh Meena, Swathy Ullas and Sanjay Kumar. 2019. Effect of Organic Manures and Bio-Inoculants on Growth, Yield and Quality of Rice (Oryza sativa L.). Int.J.Curr.Microbiol.App.Sci. 8(11): 1738-1742. doi: https://doi.org/10.20546/ijcmas.2019.811.202 